УДК $341.1 / 8$

DOI https://doi.org/10.32844/2618-1258.2019.3-2.40

КІДАЛОВ С.О., ОКОЛОВСЬКИЙ А.М.

\title{
МІЖНАРОДНО-ПРАВОВА ВІДПОВІДАЛЬНІСТЬ У КОСМІЧНОМУ ПРАВІ
}

У статті розглядаються види міжнародно-правової відповідальності у космічному праві. Міжнародно-правова відповідальність у космічному праві може бути двох видів: політична і матеріальна. Основним джерелом, що регулює питання визначення матеріальної відповідальності у космічній сфері є Конвенція про міжнародну відповідальність за шкоду, завдану космічними об'єктами. Політична ж відповідальність регулюється згідно Договору про принципи діяльності держав по дослідженню і використанню космічного простору, включаючи Місяць та інші небесні тіла.

Слід зазначити, що міжнародна відповідальність виникає у разі невідповідності космічної діяльності не лише положенням Договору про принципи діяльності держав по дослідженню і використанню космічного простору, включаючи Місяць та інші небесні тіла, але і положенням міжнародного права, включаючи Статут Організації Об'єднаних Націй.

Досліджується механізм відшкодування шкоди завданої державі. Держава, якій заподіяна шкода, може висунути державі, яка здійснювала запуск, претензію про компенсацію за заподіяння такої шкоди. Претензія про компенсацію за завдану шкоду пред'являється дипломатичними каналами, а в разі відсутності дипломатичних зв'язків із відповідною державою, яка здійснювала запуск, вона може звернутися до іншої держави 3 проханням висунути ії̈ претензію такій державі. Також вона може пред’явити претензію через Генерального секретаря ООН. Якщо врегулювання претензії не було досягнуто дипломатичними переговорами, створюється Комісія з розгляду претензій. Комісія з розгляду претензій встановлює обгрунтованість претензії про компенсацію та визначає суму компенсації, якщо вона підлягає виплаті.

Визначені недоліки міжнародного і національно законодавства України у галузі космічної діяльності. У сучасних умовах комерціалізації космічної діяльності до сфери міжнародно-правового регулювання повинні бути введені нові різновиди відповідальності, зокрема, відповідальність виробника космічної техніки, відповідальність за порушення прав інтелектуальної власності тощо.

Встановлено, що в національному космічному законодавстві повинні бути детально врегульовані питання, що стосуються діяльності неурядових юридичних осіб у космічному просторі та відповідного контролю за їх діяльністю з боку держави. Саме завдяки цьому держава може уникнути збитків, спричинених діяльністю іiї юридичних та фізичних осіб у космічному просторі.

Ключові слова: відповідальність, космічна діяльність, Конвенція про відповідальність, Договір про космос, космічний простір, міжнародна організація, Угода про Місяиьь.

The article deals with the types of international legal responsibility in space law. International legal responsibility in space law can be of two types: political and material. The Convention on international liability for damage caused by space objects is the main source governing the determination of liability in the field of outer space. Political responsibility is governed by the Treaty on principles governing the activities of States

(C) КІДАЛОВ С.О. - кандидат юридичних наук, доцент кафедри міжнародного права та порівняльного правознавства (Національний університет біоресурсів і природокористування України) ( ) ОКОЛОВСЬКИЙ А.М. - студент II курсу магістратури юридичного факультету (Національний університет біоресурсів і природокористування України) 
in the exploration and use of outer space, including the moon and other celestial bodies.

It should be noted that international liability arises in the event of non-compliance of space activities not only with the provisions of the Treaty on the Principles of the Activities of States for the Exploration and Use of Outer Space, including the Moon and other celestial bodies, but also with provisions of international law, including the Charter of the United Nations.

The mechanism of compensation for damage to the state is investigated. The injured State may file a claim for compensation for the damage caused by the launching State. Claims for compensation for damage shall be brought through diplomatic channels and, in the absence of diplomatic links with the State of origin, may apply to another State to bring a claim to that State. It may also lodge a complaint through the Secretary-General of the United Nations. If the settlement of the claim has not been reached through diplomatic negotiations, a Claims Commission is created. The Claims Commission determines the validity of the claim for compensation and determines the amount of compensation if it is payable.

The shortcomings of the international and national legislation of Ukraine in the field of space activity are identified. In the modern conditions of commercialization of space activities, new types of liability should be introduced into the sphere of international legal regulation, in particular, liability of the manufacturer of space technology, responsibility for infringement of intellectual property rights, etc.

It is established that the national space legislation should regulate in detail the issues related to the activities of non-governmental legal entities in outer space and the corresponding control over their activity by the state. This is the reason why the state can avoid losses caused by the activities of its legal entities and individuals in outer space.

Key words: responsibility, space activity, liability Convention, space Treaty, outer space, international organization, Moon Agreement.

Вступ. Дослідження і використання космічного простору - видатне досягнення минулого століття. Воно ознаменувало перехід практичної діяльності людства на новий рівень. На сьогоднішній день космічна діяльність $€$ важливим фактором сталого розвитку суспільства, показником рівня науково-технічного потенціалу держави та ефективним інструментом забезпечення іiї інтересів у галузі науки, оборони, природокористування, телекомунікацій тощо.

Нові умови сьогодення вимагають від людства теоретичної розробки питань відповідальності в космічній діяльності та ефективних процедур врегулювання спорів, відшкодування шкоди. Одним із найбільш важливих питань $є$ правове врегулювання на рівні національного законодавства 3 приводу здійснення контролю за діяльністю національних суб'єктів 3 метою забезпечення дотримання вимог міжнародного космічного права.

Тема відповідальності у міжнародному космічному праві описується у роботах таких вчених, як Г.І. Балюк, Ю.М. Крупка, М. Шмидт-Пройс, К. Стойбер, Н.Р. Малишева, Г.П. Жуков та інших.

Постановка завдання. Метою статті є здійснення правового аналізу міжнародно-правової відповідальності у космічному праві, дослідженню основних нормативно-правових актів та розгляду наявних проблем у зазначеній сфері.

Результати дослідження. Міжнародно-правова відповідальність - це юридичні наслідки, які настають для суб'єкта міжнародного права, після того, як він порушив діючі норми міжнародного права і свої міжнародні зобов'язання. Міжнародно-правова відповідальність виступає як один із юридичних засобів забезпечення дотримання цих норм і відшкодування завданої шкоди.

Особливості міжнародно-правової космічної діяльності зумовлюють специфіку відповідальності в зазначеній сфері. У космічному праві відповідальність може наставати за порушення норм міжнародного права - міжнародно-правова (політична й матеріальна) відповідальність та за порушення національного права - кримінальна, адміністративна, цивільна та дисциплінарна.

Конвенція про міжнародну відповідальність за шкоду, завдану космічними об'єктами (далі - Конвенція про відповідальність) - основне джерело, що регулює питання матеріальної відповідальності в міжнародному космічному праві. Вона була прийнята на основі положень Договору про принципи діяльності держав по дослідженню і використанню космічного простору, включаючи Місяць та інші небесні тіла (далі - Договір про космос). 
Політична відповідальність у міжнародному космічному праві знайшла своє закріплення в ст. 6 Договору про космос [1], де зазначається, що держави-учасниці Договору несуть міжнародну відповідальність за національну діяльність у космічному просторі, включаючи Місяць та інші небесні тіла, незалежно від того, провадиться вона урядовими органами чи неурядовими юридичними особами, і за забезпечення умов національної діяльності відповідно до положень, що містяться в цьому Договорі.

Діяльність неурядових юридичних осіб у космічному просторі, включаючи Місяць та інші небесні тіла, має провадитися з дозволу і під постійним наглядом відповідної держави-учасниці Договору про космос [1]. Якщо міжнародна організація порушила норми міжнародного законодавства, то відповідальність за виконання цього Договору покладається на держав-учасниць цієї організації. Це означає, що згідно зі ст. 3 даного договору міжнародна відповідальність виникає у разі невідповідності космічної діяльності не лише положенням Договору про космос, але і положенням міжнародного права, включаючи Статут Організації Об'єднаних Націй [1].

Конвенція про відповідальність детально й докладно регламентує публічно-правову відповідальність міжнародних організацій, і декларує, що міжнародні організації не можуть бути прирівняні до держав щодо передбачених для них у Конвенції прав та обов'язків. Так, якщо яка-небудь міжнародна організація відповідальна за шкоду за Конвенцією про відповідальність [2], то при дотриманні деяких умов, зафіксованих у Конвенції, ця організація і її держави-члени, що є учасниками даної Конвенції, несуть солідарну відповідальність за завдану шкоду. Якщо ж шкода завдана самій організації, то вона не може пред'явити претензію про виплату компенсації за неї, оскільки цим правом володіє не міжнародна організація, а держави-члени, що і можуть пред’явити претензію (ст. 22 Конвенції про відповідальність) [3, с. 194].

Ст. 2 Конвенції про відповідальність передбачає, що «запускаюча держава несе абсолютну відповідальність за виплату компенсації за шкоду, завдану його космічним об'єктом на поверхні землі або повітряному судну в польоті», не зазначаючи при цьому верхньої межі компенсації.

«Абсолютна» відповідальність настає у рамках легітимної космічної діяльності за заподіяння шкоди космічним об'єктом, який внесений у національний реєстр держави, що запускає. Конвенцією передбачаються можливі випадки звільнення від абсолютної відповідальності. Наприклад, коли держава, що запускає доведе, що шкода стала повністю або частково результатом грубої недбалості, дії або бездіяльності, вчинених з наміром завдати шкоди з боку держави-позивача або фізичних або юридичних осіб, яких вона представляє (ст. 6 Конвенції про відповідальність) [2].

Відносна відповідальність за заподіяну шкоду в космічному просторі (кораблям, супутникам, платформам під час їх польоту в космос, а також станціям на небесних тілах) настає у випадках, якщо вона спричинена з вини держави, що запустила об'єкт, або осіб, за яких вона відповідає.

Якщо державі заподіяна шкода, то вона може висунути претензію про компенсацію за заподіяння такої шкоди державі, яка здійснювала запуск. Претензія пред’являється дипломатичними каналами. У випадку, коли держава не підтримує дипломатичних зв'язків із державою, яка заподіяла шкоду, вона може звернутися до іншої держави з проханням висунути ії претензію такій державі. Також вона може пред’явити претензію через Генерального секретаря ООН.

Конвенція про відповідальність встановлює строк, упродовж якого може бути подана претензія про компенсацію за завдану шкоду. Відповідно до ст. 10 Конвенції, претензія про компенсацію може бути пред’явлена впродовж одного року з дати заподіяння шкоди або встановлення держави, яка здійснювала запуск і повинна нести відповідальність за шкоду. Якщо державі не було відомо про заподіяння шкоди, або вона не змогла встановити державу, яка здійснювала запуск, то тоді держава може висунути претензію впродовж одного року з дати, коли їй стали відомі такі факти. У будь-якому випадку, зазначений період не може перевищувати одного року з дати, коли за розумними припущеннями така держава могла дізнатися про факт заподіяння шкоди.

Якщо врегулювання претензії не вдалося досягти дипломатичними переговорами - створюється Комісія з розгляду претензій, яка складається з трьох членів: один призначається позивачем; другий - відповідачем; третій (голова Комісії) - спільно двома сторонами. У випадку, коли сторони не можуть спільно обрати голову Комісії, будь-яка з них має право звернутися до Генерального секретаря $\mathrm{OOH} з$ проханням призначити таку особу.

Комісія з розгляду претензій встановлює обгрунтованість претензії про компенсацію та визначає суму компенсації, якщо вона підлягає виплаті. Рішення Комісії за домовленістю сторін може бути остаточним і обов'язковим, або може містити визначення рекомендаційного характеру, 
яке сторони розглядають у дусі доброї волі (ст. 19 Конвенції про відповідальність). Дане рішення або визначення має виноситися у максимально короткий строк, але не пізніше як через рік $з$ дати його створення, якщо Комісія не вважатиме за необхідне продовжити цей строк. Після винесення рішення чи визначення Комісія передає завірену копію свого рішення чи визначення кожній зі сторін, а також Генеральному секретарю ООН [3, с. 201].

Через постійне розширенням меж та форм космічної діяльності виникає необхідність у доопрацюванні Конвенції про відповідальність чи прийнятті відповідного договору щодо кожного окремого виду відповідальності. Так, наприклад, пункт 2 ст. 14 Угоди про діяльність держав на Місяці та інших небесних тілах (далі - Угода про Місяць) передбачає, що держави-учасниці визнають, що в результаті активізації діяльності на Місяці може виникнути необхідність у детальних угодах про відповідальність за шкоду, завдану на Місяці, на доповнення до положень Договору про космос та Конвенції про відповідальність [4].

У законодавстві деяких держав містяться положення, згідно з якими передбачається відшкодування державі недержавними організаціями тих сум, які держава виплатила за завдану шкоду. Незважаючи на це, багато національних законів обмежують страхування певною максимальною сумою, яка може бути рівнозначною до максимально необхідної суми страхування відповідальності. Згідно з деякими національними законами зазначена максимальна сума може не виплачуватися у випадках, коли недержавна організація завдала шкоду умисно або, у деяких випадках, за недбалістю.

Дія Конвенції про відповідальність не поширюється на відносини між потерпілими фізичними і юридичними особами і державою, що отримала від держави запуску суму компенсації. Регулювання таких відносин - внутрішня справа цієї держави. Норми іiї внутрішнього права визначають подальший рух отриманих сум: порядок їх передачі державою фізичним та юридичним особам, метод розподілу (якщо потерпілих декілька) тощо. Водночас згаданою вище Конвенцією також не врегульовані відносини, що виникають між державою запуску та ії юридичними особами, що проводять космічну діяльність, із приводу відшкодування даною державою шкоди, що була завдана цими юридичними особами.

При прийнятті Закону України «Про космічну діяльність» не було на належному рівні враховано одну з основних особливостей міжнародного космічного права, а саме: держава несе відповідальність за дії своїх юридичних і фізичних осіб, які діють від свого імені, а не від імені або за дорученням держави (політична відповідальність); а також ту обставину, що держава запуску несе міжнародну відповідальність за шкоду, завдану космічними об'єктами (матеріальна відповідальність), у тому числі й космічними об'єктами, що є власністю окремих юридичних і фізичних осіб.

Беручи до уваги перелічені обставини, можна стверджувати, що в національному космічному законодавстві повинні бути детально врегульовані питання, що стосуються діяльності неурядових юридичних осіб у космічному просторі та відповідного контролю за їх діяльністю з боку держави. Саме завдяки цьому держава може уникнути збитків, спричинених діяльністю iii юридичних та фізичних осіб у космічному просторі. Насамперед це виявляється в результаті неналежного законодавчого регулювання «допуску» даних юридичних та фізичних осіб до космічної діяльності (вади законодавства щодо ліцензування, сертифікації, страхування) [5].

Необхідно також чітко окреслити повноваження відповідних органів державної влади й Національного космічного агентства України зокрема, що здійснюють контроль із боку держави за діяльністю юридичних та фізичних осіб [6, с. 112].

Закон України «Про космічну діяльність» не регулює питання не лише щодо відповідальності міжнародних організацій, членом яких є чи може бути Україна, а й взагалі питання участі та взаємодії України з такими організаціями. Регулювання зазначених відносин здійснюється лише статутними документами даних організацій та загальними нормами національного законодавства щодо участі в міжнародній організації. Таке регулювання, на нашу думку, вбачається недостатнім, зважаючи навіть на існування в космічному праві інституту відповідальності міжнародної організації на рівні з державою.

Окрему увагу слід приділити угодам про відповідальність, зокрема угодам про взаємну відмову від вимог про відповідальність. Згідно з пунктом 1 ст. 5 Конвенції про відповідальність, коли дві держави або більш спільно проводять запуск космічного об'єкта, вони несуть солідарну відповідальність за будь-яку завдану шкоду [2]. Зі змісту пункту 2 ст. 5 Конвенції випливає, що учасники спільного запуску можуть укладати угоди про розподіл між собою фінансових зобов'язань [2]. Такі угоди не зачіпають право держави, якій завдано шкоди, вимагати всієї компенсації 
за шкоду на підставі цієї Конвенції від будь-якої із держав запуску або всіх держав запуску, які несуть солідарну індивідуальну відповідальність. Багато угод про відповідальність не застосовуються в тому випадку, якщо відповідальність виникла в результаті навмисної або деколи грубої недбалості.

Висновки. Сучасна система забезпечення юридичної відповідальності, яка передбачається Конвенцією про відповідальність, була пристосована до умов здійснення космічної діяльності виключно державами чи міжнародними організаціями як суб'єктами міжнародного права. Це явище було природним для початку $70-x$ років, коли приймався відповідний міжнародно-правовий акт. Проте у сучасних умовах комерціалізації космічної діяльності до сфери міжнародно-правового регулювання повинні бути введені нові різновиди відповідальності, зокрема, відповідальність виробника космічної техніки, відповідальність за порушення прав інтелектуальної власності тощо. Все це потребує як подальшої еволюції міжнародно-правових норм про відповідальність за шкоду, завдану космічними об'єктами, так і відповідного розвитку національного космічного права.

Зважаючи на недосконалість національного законодавства щодо регулювання питань відповідальності при здійсненні космічної діяльності актуальним є питання про прийняття спеціального національного закону про відповідальність при здійсненні космічної діяльності або внесення відповідних змін у Закон України «Про космічну діяльність», якими на належному рівні визначалися б питання відповідальності на національному рівні, застосування положень Конвенції про відповідальність та ії реалізації, космічного страхування та інше.

\section{Список використаних джерел:}

1. Договір про принципи діяльності держав по дослідженню і використанню космічного простору, включаючи Місяць та інші небесні тіла від 27 січня1967 p. URL: https://zakon.rada.gov. ua/laws/show/995_480 (дата звернення 02.10.2019).

2. Конвенція про міжнародну відповідальність за шкоду, завдану космічними об'єктами від 29 березня 1972 p. URL: https://zakon.rada.gov. ua/laws/show/995_126 (дата звернення 03.10.2109).

3. Рубанов А.А. Международная космическо-правовая ймущественная ответственность. М. : Наука, 1977. 268 с.

4. Угода про діяльність держав на Місяці та інших небесних тілах від 18 грудня 1979 p. URL: https://zakon.rada.gov.ua/laws/show/995 482 дата звернення 03.10.2109).

5. Про космічну діяльність: Закон України від 15 листопада 1996 р. Відомості Верховної Ради України. 1997. № 1. С. 2.

6. Космічне право України: Збірник національних і міжнародних правових актів / Упоряд.: І.П. Андрушко, О.В. Бєглий; Відп. ред. Н.Р. Малишева та Ю.С. Шемшученко. 3-тє вид., перероб. та допов. К. : Юрінком Інтер, 2001. 352 с. 